old tomes and then put them aside with the thought that it was nice to know that we had such works in the university library. For me, at least, it has been an agreeable and refreshing experience to look into the excellent reprint of the 1682 edition of Nehemiah Grew's Anatomy of Plants, originally read before the Royal Society of 1672 and now reappearing as No. 11 in "The Sources of Science" series.

In a short but excellent introduction, Prof. Conway Zirkle, of the University of Pennsylvania, has reminded us of things that we ought not to have forgotten, and has directed our attention to some new and critical facets of these early studies of plant anatomy. He reminds us, for example, of the odd and remarkable fact that the microscopic study of plants and animals might well have been begun at a much earlier date, for the optical means were already available. A specially valuable part of the introduction is his critical assessment of the contributions made by the three primary exponents. Hooke, with his Micrographia published in 1665 , was first in the field. He showed what could be achieved by microscopy over a wide range of materials, but his contributions to plant anatomy, although excellently illustrated, were considerably less fundamental than those of Grew and Malpighi. Betwoen these two it was a close thing: their respective studies were submitted for publication almost simultaneously, and Prof. Zirkle has been careful and cautious in handling the relevant questions of priority and alleged plagiarism. The circumstances of the simultaneous publication of two major works make fascinating reading. So also do Grew's accounts of, and reflexions on, the structural features which he observed in his anatomical studies. Among others, for example, he gave us the term "parenchyma"; and some of his morphological observations were very much to the point.

As to the contents of Grew's book, it is with renewed surprise that one realizes how systematically thorough he was in his work and how direct and lucid in his writing. There is still an agreeable freshness, indeed modernity, in his 'discourses'. Thus, in 'the epistle dedicatory' to Charles II, he referred to the precision of the "mathematio lines of a flower"; and he stated explicitly that all we perceive in a plant, the miracle of "Nature's Handicraft" to be seen in the tissues of the meanest walking-stick, the ascent of sap, the distribution of air and of substances in plants and, indeod, many other aspects of vegetation, "are all contrived and brought about in a mechanical way". So we enter into a new world "whereof we see no end". The numerous original illustrations, here reproduced with fidelity, are still impressive because of their observational content, clarity and, not least, their sheer artistic quality. Of course, at 35 dollars, this volume is something of a collector's piece; but many would, undoubtedly, liko to possess it. It might be salutary, and it would certainly be no bad thing, if it were made available for at least occasional student reference.

C. W. WARDLAW

\section{BIOLOGICAL CONTROL OF ROOT DISEASES}

Ecology of Soil-Borne Plant Pathogens

Prelude to Biological Control. Edited by Prof. Kenneth F. Baker and Prof. William C. Snyder. (An International Symposium on Factors determining the Behavior of Plant Pathogens in Soil, held at the University of California, Berkeley, April 7-13, 1963.) Pp. 571. (London: John Murray, 1965.) 105s. net.

$\mathrm{D}^{1}$ ISEASED roots of crop plants are less amenable to chemical control than diseased leaves, and they are also more difficult to examine, if only because soil is opaque and complex. Applying fungicides and sterilants on a field scale is usually prohibitively expensive; consequently the possibility of biological control by manipulating the microflora becomes correspondingly attractive, and, although successful in only a few cases with present knowledge, much is promised for the future.

As the editors point out in the foreword to Ecology of SoilBorne Plant Pathogens, exploration of this difficult subject "awaited the overcoming of . . . compartmentalization of the scattered, diffuse, isolated and uncorrelated knowledge" in the disciplines of plant pathology, microbiology, soil science, plant physiology, plant anatomy, biochemistry, bacteriology, nematology, mycology, virology and zoology. For this reason, the Agricultural Board of the National Academy of Sciences-National Research Council, Washington, sponsored an international symposium on factors determining the behaviour of plant pathogens in the soil, with the object of assembling a group of specialists to compile and discuss existing information in preparation for further advances towards biological control. The conference was held at Berkeley, California, in April 1963. Generous financial aid brought together more than forty experts to present formal papers before an invited audience of more than three hundred participants from twentyfour countries.

The papers and recorded discussions are now published in a handsome (and weighty) volume, edited by two of the leading spirits in the group which initiated the conference. The resulting volume provides an invaluable course on the principles of soil microbiology in relation to root diseases. Individual papers are usually introduced by a critical survey of relevant literature, leading on to an exposition of the special topics studied by the author with an account of his own researches and conclusions, and ending often with a more speculative section that could stimulate further developments. There are copious bibliographies and, as inevitable in a symposium of this kind, there is some repetition because certain key papers are cited again and again, as the work of some authors is discussed from different angles.

Readers of the half-million or so words of this book will agree with the opening speaker, Victor $R$. Boswell, that it represents a landmark in biology. The first main paper, by S. D. Garrett, deals with fundamental concepts and prospects for the future of biological control of root diseases. Thereafter groups of papers deal with topics of increasing complexity. Soil microbes and their behaviour are surveyed by A. Burges, D. K. McE. Kevan, J. H. Warcup, J. M. Hirst, D. Park, A. S. Sussman and J. D. Menzies. Then the soil is considered as an environment for microbes by W. A. Raney and H. D. Chapman. Next, attention is focused on the host plant, particularly its roots and rhizosphere, by Flora M. Scott, H. G. Burström, A. D. Rovira, H. Katznelson, D. J. D. Nicholas, J. L. Harley, P. S. Nutman and A. Kerr. Host and pathogen are then brought together in a series of papers by N. T. Flentje, I. W. Buddenhagen, W. B. Mountain, C. H. Cadman, J. C. Walker, J. E. DeVay and I. A. M. Cruickshank. Mechanisms of microbial antagonism are considered by F. E. Clark, R. A. Fox, R. M. Jackson, M. G. Boosalis and R. Mankau. Theoretical aspects of soil inoculum are developed by R. Baker, A. E. Dimond and J. G. Horsfall. The final section is the most complex and deals with interactions between soil organisms and crop plant in a series of papers by Mary D. Glynne, G. C. Papavizas, Z. A. Patrick, T. A. Toussoun, T. S. Sadasivan, R. A. Ludwig, G. W. F. Sewell, W. A. Kreutzer, S. Wilhelm and A. W. Dimock.

The editors have maintained an exacting standard throughout their formidable task of dealing with papers, discussions, bibliographies, and an index of thirty-six pages. For its wealth of material this splendidly produced volume is a necessity in every centre where plant pathology is taught or practised. As one consequence, the Berkeley symposium has stimulated plans for the First International Congress of Plant Pathology in London in 1968. Another consequence will be eager searching of its records for clues to help fill hungry bellies.

P. H. Gregory 